\title{
Critical Rhetorics of Controversy
}

\author{
Kent A. Ono and John M. Sloop
}

We appreciate the opportunity to respond to the many issues raised in Kendall Phillips's (1999a) essay "A Rhetoric of Controversy" and Thomas Goodnight's (1999) essay/response Mssrs. Dinkins, Rangel and Savage in Colloquy on the African Burial Ground: A Companion Reading." Our interest in "controversy" and "the political," among other issues they raise, leads us to respond to their arguments, to draw some connections to our own work where relevant, and, hopefully, to expand the terms of the conversation between Phillips and Goodnight in order to encourage other scholars interested in these subjects to participate in the discussion.

$\mathrm{O}$ VER THE PAST SEVERAL YEARS, we have been engaged in discussions regarding critical rhetoric and, indirectly, issues of the public sphere. We welcome the chance to comment specifically on issues affecting "the political" more directly here. ${ }^{1}$ For this colloquy, we respond to the two new essays by Kendall Phillips and G. Thomas Goodnight as well as other relevant research. We cannot help but read Phillips's (1999a) essay in the context of another recent essay (1999b) of his that appeared in Philosophy and Rhetoric [hereafter $P \& R$ ], and that responded to an earlier $P \& R$ essay (1997) we wrote ("Out-law Discourse: The Critical Politics of Material Judgment"). Because our original piece in $P \& R$ is a detailed examination of the political theories of both Jean François Lyotard and Chantal Mouffe, ${ }^{2}$ who also are the subjects of two of Goodnight's essays (1995, 1999), we respond to Goodnight's earlier essays as well.

We begin by noting a few points of common interest in the two new essays. Both Phillips and Goodnight express distinct interest in issues of the public sphere, though from statedly different positions. Both see a discussion of controversy as beneficial and both encourage more conversation about the study and theorization of controversy. Both regard the case of the New York City African Burial Ground as worthy of examination and ultimately of praise. Both seek to expand the rhetorical resources available for rhetors. Both concern themselves

KENT A. ONO (Ph.D., University of Iowa, 1992) is Associate Professor in the American Studies Program and in the Asian American Studies Program at the University of California, Davis, Davis, CA 95616-8518. JOHN M. SLOOP (Ph.D., University of Iowa, 1992) is Assistant Professor in the Department of Communication Studies at Vanderbilt University, Nashville, TN 37235. 
with issues of marginality and the public sphere. While the commonalities do not end there, we only mention these few in order to suggest that despite the contestive nature of much of the language in these essays, there is much in common to both.

\section{Phillips}

In response to several essays by Goodnight, some of them coauthored, Phillips (1999a) examines the rhetoric surrounding an African burial ground in New York City in order to build on Goodnight's (1991) call for more research on controversy. Phillips's essay logically follows his earlier essay (1996) on dissension, which challenges what he sees as a predisposition toward seeking the telos of consensus assumed within public sphere research. In his most recent essay (1999a), Phillips is interested in "the emergence of oppositional arguments that render the frameworks for deliberation problematic" (p. 489), and he wants to expand the spheres of argumentation through "reflection on discursive conventions and habits, and draws more and more communicative practices and regularities into a traditional arena of public deliberation (p. 489). Focusing primarily on Goodnight's research, Phillips (1999a) contends that public sphere discourse tends to flatten time and space in favor of dominant institutional forces, thereby closing down and containing the potential disruptiveness of resistant discourses. Phillips chooses a strategy for reading discourses that emphasizes the disruption and disorientation caused by social actors who tactically seize the moment and create the potential for a change of public assumptions about, among other things, history. According to Phillips, such disrupting and disorienting acts may lead to a more profound displacement of regularized institutional patterns and discourses and their (at least temporary) replacement with new ones.

The case of the African Burial Ground is an intriguing one. The Federal General Services Administration (GSA) began a construction project in 1991 near City Hall Park in New York City. Upon finding the bones of African slaves dating back to 1690, construction halted, then resumed until public criticism and political maneuverings led a U.S. House of Representatives subcommittee overseeing the GSA to intervene and hold a fact-gathering meeting. What was initially treated as a fait accompli by the GSA, which continued to articulate its authorial logic over the situation to the very end, suddenly was disrupted when protesters and African American luminaries successfully intervened, appealed to a higher authority, and ultimately displaced the GSA's power over the site and replaced it with a politically emergent one.

While we are sympathetic to Phillips's overall attempt to bring "controversy" to the forefront as a potentially fruitful site for examination, and while we ourselves embrace much that we might label "poststructural" within his theorizing (e.g., disrupting authoritative 
logics and institutions and embracing the provisional nature of associations, subject positions, and power), we would like to raise four brief concerns about his essay.

First, many critical challenges to public sphere research have already been made (e.g., see the list of critical works Goodnight and Hingstman discuss in their 1997 review). By rehashing this critique and positioning the rhetoric of controversy in response to public sphere research, versus, say, in response to "critical rhetoric" research, Phillips needlessly recenters a quite possibly now-defunct version of public sphere research within the field, a version from which Goodnight overtly distances himself.

Second, it is unclear to us how the outcome of the controversy over the African Burial Ground is a politically desirable one. Phillips implies that the ultimate conclusion of the ordeal, the creation of a memorial at the site, is liberatory when in fact, while it problematizes a certain positioning of authority, it repositions another one that rearticulates governmental authority over land disputes. As Phillips characterizes it, "On July 30th the General Services Administration permanently halted digging at the cemetery site. Early in 1993 the African Burial Ground was made an official historical landmark" (pp. 503-504). We imagine many critical scholars might read this as saying, "See, the system works just fine." However, are "official" historical landmarkswhich in many ways signify the power of the state, if not the dominance of state power generally-forms of radical resistance for African Americans, for African Americans in New York, and for other communities whose histories have been ignored and/or marginalized?

Third, we pause over Phillips's conceptualization of the role of academic criticism. In assessing our (1997) approach to criticism in the outlaw discourse essay, Phillips (1999b) writes that "Rather than academic criticism acting in service of everyday acts of resistance, everyday acts of resistance are put into the service of academic criticism" (p. 97). Herein, Phillips both suggests academic criticism plays no role in the realm of politics and seems to indicate that the only way any of us speaks or writes is through academic criticism. We suggest that everyday acts of resistance-most notably those that are incommensurable with dominant logics-inform and should be part of one's own politics. That is, we are not suggesting that one looks for outlaw discourses or controversies solely in order to write "academic criticism" about them; we are suggesting (and this is certainly not new) both that one views one's "academic criticism" as political and that one see one's task as moving outside of some limited understanding of what "academic criticism" can do. What occurs in Phillips's essay is a conflation of "controversy" and "incommensurability." In our "Out-law" essay, we are attempting to encourage critics to look for cases of "the differend" or "incommensurability" (which requires that one take into account various logics and their power relations), rather than cases of disagree- 
ment (which are seen as differences of opinion, not differences in the relative power of logics and positions), in order to provide a radical rethinking of the possibilities for any given discourse.

A controversy that is part of a commensurable discourse is one in which two or more positions disagree on the outcome of a shared question (e.g., How should this burial ground be treated?). In cases of commensurable controversies, shared logics and institutions are used to reach a conclusion (through, for example, public sphere discussions or the court system) and to enact that solution (e.g., via the Park Service or the Smithsonian). In incommensurable controversies, the legitimacy of the logics and institutions employed are at base being undermined. Hence, an outlaw discourse might not recognize even the right of the city/state of New York to have a position on the grounds. An outlaw logic might not recognize the right/legitimacy of a US government institution to care for land that contains bodies which the outlaw logic situates as transcending the legitimacy of the very system that allowed for the unseemly deaths and burials. An outlaw critique looks for logics that could potentially undermine dominant logics rather than for controversies that illustrate how well it works. In short, while Phillips seeks a logic other than the one the GSA asserts (a bureaucratic, linear, one-solution-to-every-problem-like-this-one logic), he ultimately praises a logic that counters the GSA's logic on the GSA's own grounds; he does not look outside existing dominant logics.

\section{Goodnight}

Goodnight's (1999) response to Phillips centers on his perception that Phillips is engaged in a project of anti-essentialism. Aligning himself primarily with Mouffe (1996) Goodnight rejects both essentialism and anti-essentialism, viewing both as insufficient grounds for mobilizing toward the political. Like Mouffe, Goodnight suggests rhetoric that performs a "we" is necessary to the political; thus, a rhetoric based on difference that cannot distinguish between positions is insufficient to recover provisional affiliations. Goodnight argues that Phillips's approach distances the critic from the controversy; uses "negative" terminology, which he says provides no opening for study of the text to inform theory; and sees appeals not thought to be properly oppositional as creating dissension.

Goodnight reexamines the case of the African Burial Ground by looking specifically at the opening addresses given by Dinkins, Rangel, and Savage, all of which appeared in a government document publication. Goodnight's rereading of the meeting calls attention to nuances missed in Phillips's analysis of Dinkins's address, such as Dinkins's extension and expansion of the dialogue. Goodnight reads Dinkins's discourse as expanding the GSA's own limited sense of its role as well. Goodnight comments on Rangel's comments, which Phillips does not 
discuss, and compares what he thinks a critic like Phillips might have said about Rangel's address to Goodnight's own approach, an approach that appreciates artful language, imaginative inventional aspects, and the potential to generate further conversation and expand rhetorical resources. Goodnight also rereads Savage, emphasizing Savage's pragmatic approach to utilizing decorum to establish a context within which to discuss a matter of importance. Goodnight ultimately argues for an appreciation of the aesthetic dimensions of the text, especially its "art" and "beauty" as a possible way to create potential public affiliations.

The central significance of Goodnight's recent work is his call for renewed political engagement on public issues of importance. Whether discussing the controversial (Goodnight 1991, 1995; Olson \& Goodnight, 1994) or "the public sphere" (Goodnight \& Hingstman, 1997), Goodnight stresses the need for political engagement. Aligning himself with recent work by Jurgen Habermas ${ }^{3}$ and Chantal Mouffe, Goodnight concerns himself with the increasing privatization of the economic and the political; with public apathy resulting from increasingly aggressive corporate public relations discourse; with postmodern skepticism and complacency accelerated by ever-more-efficient (and viscerally pleasurable) advertising practices; as well as with an overall skeptical outlook taken by many in the academy. In his recent review essay with Hingstman (1997), Goodnight also carefully addresses issues of race, gender, and sexuality as they impact contemporary public sphere research.

Goodnight's call for renewed political activism and communication about the political is certainly welcome. Indeed, we appreciate the fact that he continues to call attention to the risks of skepticism and complacency within the academy and in society generally, a point similar to one we, ourselves, have mentioned as well (1992). Nevertheless, while we are allied with Goodnight on this point, there are aspects of Goodnight's work that concern us.

First, despite citing and reviewing texts critical of public sphere research, Goodnight does not sufficiently clarify the ways his own theoretical project has changed as a result of influences by feminist, poststructuralist, and ethnic studies scholarship. By not foregrounding these changes, Goodnight makes a circuitous pattern around these perspectives, while nevertheless being influenced by them; hence, he misses an opportunity to bring marginalized discourses and theories to the fore. We suggest that a different tactic would be to highlight the ways that poststructural, feminist, ethnic studies, and cultural studies scholarship has challenged public sphere scholarship (e.g., see Black Public Sphere Collective, 1995; Fraser 1989, 1992; Zulick \& Laffoon, 1991) and to note the ways that historical public sphere scholarship, in general, may have the effect of further marginalizing already-marginalized research. 
Second, Goodnight's notion that we are currently in a period of protracted skepticism needs to be historically grounded. Indeed, even if our present era is marked by increasing skepticism and apathy, is it not possible, like the "lull before the storm," to read historical periods as contingent? Hence periods of unrest would be followed by reflection and ultimately change? Further, Goodnight does not explain how critical skepticism is related to political apathy. On the face of things, those who are rigorously, indeed relentlessly, critical of contemporary society and culture strive to build community through their criticism. Thus, in one reading, it is precisely those who are most critical-who are willing to take the risks, to cross the boundaries, to speak the unspeakablewho give people the courage to participate in the political.

Third, Goodnight reads Mouffe (1996) as providing evidence that too much skepticism leads to an evacuation of the political. However, he does not note that she frames her essay not as a critique of postmodernism, but, in fact, as a response to essentialist humanism, universal reason, and individualism-what many would think of as the basic tenets of traditional public sphere scholarship. ${ }^{4}$ While selective use of the work of a theorist is not necessarily problematic, in this case Goodnight's use of Mouffe allows him to critique the work of Phillips for its negative standpoint without forcing himself and all of us to problematize our own work. Instead, Goodnight rereads some of his previous work as if it already implies Mouffe's argument. In our minds, it would be more beneficial to place past public sphere scholarship in critical conversation with various assumptions made in the present, thereby forcing us to rethink those positions rather than simply allowing previous work to slip seamlessly into one's current assumptions.

Fourth, in his 1995 essay, in calling for a renewed interest in issues of political import, Goodnight unfortunately conflates critical "postmodern" thinkers in the academy with corporate, economic "postmodern" culture, both of which he suggests are part of the same political apathy resulting in the decline of public sphere activity. In referencing Lyotard, Goodnight ultimately conflates Lyotard, the scholar, with the subject of Lyotard's discourse, the "postmodern condition," and posits Lyotard's discourse more as symptom of postmodern culture than as strategy in response to it.

Fifth, Goodnight's 1995 article constructs oppositions that are unnecessary to his argument. Whereas the public sphere is the location of prudent, "rational" decision-making, contains political import and demonstrates real "commitment to the public realm" (p. 269), postmodernism is "divisive," "alienating," "cynical," "mean-spirited," and "offputting"; it is "suspicious" and "cynical" (p. 272); it shows "anger" and "resentment" and can often be found "ballyhooing difference" (p. 272). Whereas modernists prefer "public involvement," postmodernists prefer "the security of private life" (p. 272). Whereas modernism has a "public sphere," postmodernism is "highly fragmented" and tends to- 
ward schizophrenia (p. 272). Whereas modern rhetoric is "nostalgic," postmodernist rhetoric is "skeptical" (p. 271). Whereas traditional rhetoric engages in agon-good spirited competition, and aleasensible risk-taking, postmodern rhetoric engages in mimicry, donning the mask of oppressive power for selfish ends, and ilinx, "dizziness and disorder" producing simultaneously ecstasy and obfuscation (p. 271). Whereas modern rhetoric defers to "reason," postmodern rhetoric defers to "will" (p. 275).

Whether or not intended, the general tenor of his essay implies that anyone who identifies with theory labeled as "postmodern" (e.g., the work of Baudrillard, Foucault, and Lyotard) $)^{5}$ may, inadvertently, also be contributing to the decline of the public sphere. While Goodnight's critique is perhaps justified as a critique of private, corporate capitalism and advertising rhetoric, in critiquing Lyotard, Goodnight's approach, in fact, makes it difficult for many with ostensibly similar interests to his own to want to walk side by side with him. In his (1995) essay in particular, Goodnight shows very little interest or concern in work many of us are engaged in, namely academic critiques (socialism, marxism, feminism, cultural studies, poststructuralism, postcolonialism, deconstructionism, and anti-racism) of very real oppressions of our times.

Finally, while Goodnight addresses many historical forces leading to the evacuation of the political, he does not address those that many poststructural scholars have said influence their political projects, namely the rise of fascism during World War II and the failed student political movements for social justice (e.g., in France), which more or less ended in May 1968. At least since the end of World War II, critical theorists, including many members of the Frankfurt School, have been engaged in a long-term theoretical project to eliminate the potential for yet another rise of despotic fascism. We think this telos, in part, explains the very often relentless critique of social institutions and political ideology, and the tendency to challenge authority, in general, for political actions that may tend to consolidate forces against those in marginalized social positions. Indeed, Auschwitz is a specter that haunts Lyotard throughout The Differend; (1988) the very existence of the horrors of fascism act for Lyotard as the impetus for finding ways to adjudicate claims that do not necessitate the $a$ priori illegitimacy of one language game in favor of another. It would be useful for Goodnight to address the fact that challenges to authority take place precisely because the decisions of those with institutional power very often have the widest and most profound long-term effects.

Furthermore, in his afterward to Power/Knowledge, Colin Gordon (1980) discusses the role the failed student movements in France in 1968 played in changes in theorization in Foucault's work. Those following Foucault and others became concerned with the diffusion of resistances to various parts of the social sector, with localized resis- 
tances, as well as with universities'-which are continually becoming privatized-contributions to the diminishment of political struggles and to particular institutionalized practices of discipline replete throughout society. Arguably, those interested in Foucault's work have critiqued often invisible and silent political and institutional forces as part of an overall engagement with the political.

Postcolonial research also takes a critical approach to contemporary culture; it too, is skeptical of universalist/colonialist conceptions of the political. Such research highlights and challenges the role of Western, colonial discourse and knowledge in circumscribing the contemporary social world in which we live, and often calls attention to the roles rhetoric and academic criticism play within neo-colonial contexts (e.g., see Shome, 1996; Wander, 1996).

\section{Our Perspective}

In order to elaborate some of our own work in relation to conceptualizing resistance, controversy, and the public, we begin with a brief discussion of both Goodnight's and Phillips's handling of the African Burial Ground example. What we object to in both essays is that they end up valorizing the legitimating features of the state. Both end up praising Mayor Dinkins. Both rely on institutional sources-Phillips on the New York Times, and Goodnight on government documents (sources provided by institutions with authority and ethos deriving from economic and political power)-as acceptable speakers for African Americans. Both, in our minds, move too quickly to praise social change afforded by arguably instrumental institutional means and give short shrift to asking whether appeals to Congressional subcommittees and the like are acceptable means of resistance that should be encouraged. The analysis of the New York Times is particularly surprising and contradictory in the case of Phillips's essay, since his criticism of research on the public sphere challenges it for focusing too much on commensurate discourses. In Phillips's assessment of the "discourse" of the African Burial Ground, however, what we get is the discourse of/about the African Burial Ground through the lens of New York Times reporters. We do not get direct comments from the participants in the controversy, nor from the African American vernacular press, for instance; rather, we get an assessment of what happened through an acceptable, privileged, dominant institutional lens with its own economic interests in covering the issues, and in doing so in its own partisan ways.

In Phillips's response to our essay on outlaw discourse, he suggests that, as critics, we should not examine marginalized discourses for fear of doing harm to marginal communities. Instead, he suggests that "interrogating (in-law) discourses for their incongruities and contradictions, not turning the academic gaze upon those communities wanting 
for an opportunity" is a desirable alternative (p. 100). ${ }^{6}$ Phillips is correct to be wary of unwanted interventions, of submitting marginalized communities to the gaze of the state, of further marginalizing as a result of critical analysis, and of questioning the role of criticism as a political act. In fact, our own essay also conveys those concerns. Further, our 1995 essay on vernacular discourse entails not only examination of marginalized discourses, but also critical analysis of dominant discourses, of the kind Phillips (1999a) promotes in his essay.

Had Phillips or Goodnight examined discourse of the Black vernacular press, conducted conversations with leaders in the Black community in New York, examined speeches and interviews on Black vernacular radio programs, contacted people via e-mail, or the like, we argue that their analyses would have been stronger, their research would have been richer, and their comments on how rhetoric functions would have been enhanced. In this way, we suggest logics outside of the dominant institutions (e.g., the dominant press) might have been brought to the fore. Rather than seeing the halting of construction and the erecting of a monument as a mode of resistance, perhaps contradictory positions-antagonistic and dissenting statements-might have been made. As Zulick and Laffoon (1991) suggest, "It is the diversity of the public sphere" in the form of "enclaved" and "counter-publics" that "provides the materials for critique" (p. 252).

What we were trying to suggest in our (1997) "Out-law" essay is that processes of assimilation are oppressive and violate democratic principles. Such processes are processes of erasure; they forward one culture above another in a hierarchicalized, forced socialization to a given hegemony. Thus, given that there is by necessity a multiplicity of contexts presently framed in relations of subordination, we ask what kind of theory would be necessary to alter the relations of power in such a way that cultural, economic, and physical violence, and the discipline conducted, would not be applied to some people in order to press them into becoming more like others? Such a question necessitates social change and the crossing of social boundaries. Indeed, it necessitates cultivating an interest in experiences of cultures other than one's own. It also necessitates appreciation and respect for logics that, because of one's own experiential limitations, may appear quite absurd at the outset. Hence, in the 1997 essay we set out, as per Laclau and Mouffe's (1985) agenda, to search for a collective identity, a "we," "that would articulate the demands found in the different struggles against subordination" (Mouffe, 1996, p. 247).

We also set out to eliminate the narcissism associated with the idea that a single person or group is able to summon up within herself or itself the total realm of subordinated logics - the already existent logics that may differentially be operating in local contexts as well as having larger effects within the community. And here is where we (1997) disagreed with Mouffe (1993): She regards the religion of Islam as de facto 
unassimilable into her conception of politics (p. 59), because in her view religion must be a private matter, and since Islam is both public and private in practice, in order to be part of the respublica, practitioners of Islam also would have to consent to seeing it as private. Her conception of politics takes for granted the necessity of a "permanent," "constitutive outside" (1993, p. 69) and requires participants to "accept submission to the rules prescribed by the respublica in seeking their satisfactions and in performing their actions" (1993, p. 69); it, thus, goes well beyond collaboration out of a common interest in the political and a common interest in striving for both liberty and equality. ${ }^{7}$

We sought a role for the critic and for criticism to seek outlaw logics, whether or not we, ourselves, were operating out of the logics being used to regulate and adjudicate within dominant society. We did not assume the critic would be able to create, know about, or even find logics counter to the dominant logics. Rather, our goal was to insist that-in order to address the incommensurability of groups based on race, class, gender, class, sexuality, nation, and other subordinating structures, processes, and logics-subjects would have to cultivate an interest in cultural artistic expressions, ways of living, and principles of survival contrary to those generally referenced in contemporary popular discursive forums.

Of course we were wary that such a project-seeking out outlaw discourses and bringing those logics (not necessarily the people) into some connection with dominant logics and people-could not be done without some risk. The potential for further marginalization is always possible; the potential for a backlash, too, is possible. Another potential danger is the possibility of objectifying those logics and introducing them in a way that was not anticipated, wanted, or desired. Further, we recognized, from the outset, our privilege as critics: We recognize both the system that allows us movement, leisure time, and access to information and resources that necessarily circumscribe the production of our theory, and the need to bring logics that challenge and perhaps confound dominant logics to the fore.

In that (1997) essay we also challenged an implied hierarchical relationship in Laclau and Mouffe's (1985), as well as in many other theorists', work between the "we" of the respublica and the "wes" within autonomous organizations, and the logics, geographies, and politics that do not simply "add to," "blend into," or acquiesce to those who put the "we" public above the more powerful and pressing collectivities. Thus, we advocate the construction of a collective identity not unlike the one Mouffe describes. However, we recognize that identity changes, that there will always be some with the privilege to have more or less power to influence that collective, and that collective identity itself does not have any necessary $a$ priori status over other forms of identity.

Like Mouffe, we embrace antagonism as a necessary effect of a social system organized on principles of subordination, and as a way of seeing 
the world that relies on the reality of the enactment of some of Goodnight's very principles. Our intention, given our overall political philosophy, is to embrace a particular way of thinking about challenging the social institution: identifying particular logics that are, in fact, either in tension or wholly in contrast to the logics within dominant sectors of society. If it is true, as Mouffe (1996) suggests, that hegemony is provisional, that given policies depend on who happens to form them and at what time they are formed, then our goal is to invigorate the process-indeed, to accelerate the speed-with which encounters between dominant logics and outlaw logics come into contact, into view, and into tension. The basic problem with discussing a generic and universal "public sphere" is that all too often the only models made available to large populations of people through dominant media channels are those that already have ethos because of their familiarity. Publics that may sometimes function as counter-publics rarely get adequate air time to be understood or evaluated, let alone to become models for larger social organizing.

What we hope we have done in this short response to the essays by Goodnight and Phillips is to raise a third specter, a third set of questions. This is not an attempt by any means to provide closure to the arguments and disagreements; instead, we seek to continue to problematize an area of research that becomes ever more complicated and more critical as it matures. In the end, what we hope we have added to this discussion is the understanding that investigations of rhetorics of controversy can also include investigations of the rhetorics of incommensurability. Criticism should not only discuss the ways in which politics occurs in controversy and the ways in which various positions can work within existing structures; it also can, and should, investigate the development of logics and understandings that are incommensurable with current systems. There may be times when the rhetoric of the outlaw is a rhetoric with a logic that may prove more useful than the current rhetorics that institutions allow.

\section{NOTES}

${ }^{1}$ Goodnight's work vacillates in its use of the terms "public sphere" and "the public." If he were to accept Nancy Fraser's $(1989,1992)$ terms, and Margaret Zulick and Anne Laffoon's (1991) terms, he would use "enclaved" publics or "counterpublics" versus "the public sphere" as his primary term. The metaphor of a "sphere," as well as the baggage of universalism that follows the term, not to mention the false dichotomy between private and public identified largely, but not entirely, by a feminist critique, should render the term obsolete. The concept "the political," on the other hand, addresses the need and desire for activism, which is not necessarily implied by the term "public sphere," which instead very often signals government policy and a system of institutional arbitration, hence very often maintenance of things as they are.

${ }^{2}$ See, for example, Lyotard and Thebaud (1985), Lyotard (1984), and Mouffe (1993, 1996).

${ }^{3}$ See, for example, Habermas (1992).

${ }^{4}$ For instance, on the first page Mouffe (1996) writes: "Indeed, I am going to argue that it is only in the context of a political theory that takes account of the critique of 
essentialism-which I see as the crucial contribution of the so-called postmodern approach - that it is possible to formulate the aims of a radical democratic politics in a way that makes room for the contemporary proliferation of political spaces and the multiplicity of democratic demands" (p. 245).

${ }^{5}$ See, for example, Baudrillard (1993, 1988, 1987), Foucault (1978), Lyotard (1985).

${ }^{6}$ In doing so, Phillips is suggesting that examination of dominant discourses does not further marginalize vernacular texts.

7Within Mouffe's (1996) conception, for instance, one form of participation, which may in some instances necessitate not participating, would fall outside of the "rules prescribed by the respublica."

\section{REFERENCES}

Baudrillard, J. (1993). Symbolic exchange and death (I. H. Grant, Trans). London: Sage. (original work published in 1976).

Baudrillard, J. (1988). America (C. Turner, Trans.). London: Version (Original work published in 1986).

Baudrillard, J. (1987). Forget Foucault (N. Dufresne, Trans.). New York: Semiotext(e). (Original work published in 1977).

Black Public Sphere Collective. (Eds.). (1995). The black public sphere: A public culture Book. Chicago: University of Chicago Press.

Foucault, M. (1978). The history of sexuality. Vol 1. An Introduction (R. Hurley, Trans.). London: Allen Lane.

Fraser, N. (1992). Rethinking the public sphere: A contribution to the critique of actually existing democracy. In C. Calhoun (Ed.), Habermas and the public sphere (pp. 109-142). Cambridge, MA: MIT Press.

Fraser, N. (1989). Struggle over needs: Outline of a socialist-feminist critical theory of late captialist political culture [sic]. In Unruly practices: Power, discourse and gender in contemporary social theory (pp. 161-187). Minneapolis: University of Minnesota Press.

Goodnight, G. T. (1999). Messrs. Dinkins, Rangel, and Savage in colloquy on the African burial ground: A companion reading. Western Journal of Communication, 63, 511-525.

Goodnight, G. T. (1995). The firm, the park and the university: Fear and trembling on the postmodern trail. Quarterly Journal of Speech, 81, 267-290.

Goodnight, G. T. (1991). Controversy. In D. W. Parson (Ed.), Argument in controversy: Proceedings of the seventh SCA/AFA conference on argumentation (pp. 1-13). Annandale, VA: Speech Communication Association.

Goodnight, G. T., \& Hingstman, D. B. (1997). Studies in the public sphere. Quarterly Journal of Speech, 83, 351-399.

Gordon, C. (1980). Afterword. In M. Foucault (C. Gordon, Ed.), Power/knowledge: Selected interviews and other writings, 1972-1977 (pp. 229-259). New York: Pantheon.

Habermas, J. (1992). Further reflections on the public sphere (T. Burger, Trans.). In C. Calhoun (Ed.), Habermas and the public sphere (pp. 421-461). Cambridge, MA: MIT Press.

Laclau, E., \& Mouffe, C. (1985). Hegemony and socialist strategy: Towards a radical democratic politics. New York: Verso.

Lyotard, J. (1988). The differend: Phrases in dispute (G. Van Den Abbeele, Trans.). Minneapolis, MN: University of Minnesota Press. (Original work published in 1983.)

Lyotard, J. (1985). Just gaming (W. Godzich, Trans.). Minneapolis, MN: University of Minnesota Press. (Original work published in 1979).

Lyotard, J., \& Thebaud, J. L. (1984). The postmodern condition: A report of knowledge (G. Bennington \& B. Massumi; Trans.). Minneapolis, MN: University of Minnesota Press. (Original work published in 1979). 
Mouffe, C. (1996). Democracy, power, and the "political." In S. Benhabib (Ed.), Democracy and difference: Contesting the boundaries of the political (pp. 245-256). Princeton: Princeton University Press.

Mouffe, C. (1993). The return of the political. London: Verso.

Olson, K. M., \& Goodnight, G. T. (1994). Entanglements of consumption, cruelty, privacy, and fashion: The social controversy over fur. Quarterly Journal of Speech, 80, 249-276.

Ono, K. A., \& Sloop, J. M. (1995). The critique of vernacular discourse. Communication Monographs, 62, 19-46.

Ono, K. A., \& Sloop, J. M. (1992). Commitment to telos: A sustained critical rhetoric. Communication Monographs, 59, 48-60.

Phillips, K. R. (1999a). A rhetoric of controversy. Western Journal of Communication, 63, 488-510.

Phillips, K. R. (1999b). Rhetoric, resistance, and criticism: A response to Sloop and Ono. Philosophy and Rhetoric, 32, 96-102.

Phillips, K. R. (1996). The spaces of public dissension: Reconsidering the public sphere. Communication Monographs, 63, 231-248.

Shome, R. (1996). Postcolonial interventions in the rhetorical canon: An "other" view. Communication Theory, 6, 40-59.

Sloop, J. M., \& Ono, K. A. (1997). Out-law discourse: The critical politics of material judgment. Philosophy and Rhetoric, 30, 50-69.

Wander, P. (1996). Marxism, post-colonialism, and rhetorical contextualization. Quarterly Journal of Speech, 82, 402-435.

Zulick, M. D., \& Laffoon, E. A. (1991). Enclaved publics as inventional resources: An essay in generative rhetoric. In D. W. Parson (Ed.), Argument in Controversy: Proceedings of the Seventh SCA/AFA Conference on Argumentation (pp. 249-255). Annandale, VA: Speech Communication Association. 